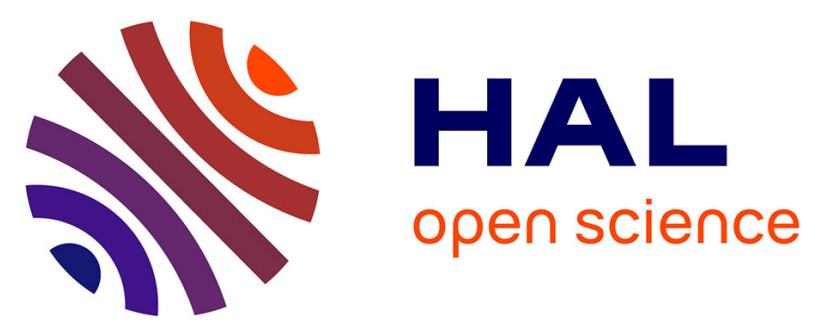

\title{
A database for spatial variability assessment of mechanical parameters of Ozigo specie under long-term bending tests in Gabon
}

\author{
Rostand Moutou Pitti, Valérie Nsouami, Nicaise Manfoumbi, Emilio \\ Bastidas-Arteaga
}

\section{To cite this version:}

Rostand Moutou Pitti, Valérie Nsouami, Nicaise Manfoumbi, Emilio Bastidas-Arteaga. A database for spatial variability assessment of mechanical parameters of Ozigo specie under long-term bending tests in Gabon. SEMC 2019: The Seventh International Conference on Structural, Sep 2019, CapTown, South Africa. hal-02116765

\section{HAL Id: hal-02116765 \\ https://hal.science/hal-02116765}

Submitted on 1 May 2019

HAL is a multi-disciplinary open access archive for the deposit and dissemination of scientific research documents, whether they are published or not. The documents may come from teaching and research institutions in France or abroad, or from public or private research centers.
L'archive ouverte pluridisciplinaire HAL, est destinée au dépôt et à la diffusion de documents scientifiques de niveau recherche, publiés ou non, émanant des établissements d'enseignement et de recherche français ou étrangers, des laboratoires publics ou privés. 


\section{A database for spatial variability assessment of mechanical parameters of Ozigo specie under long-term bending tests in Gabon}

\section{Nsouami}

Ecole Normale Supérieure L'Enseignement Technique, BP 8939 Libreville, Gabon

E. Bastidas-Arteaga

UBL, Université de Nantes, GeM, CNRS UMR 6183/France

R. Moutou Pitti

Université Clermont Auvergne, Université Blaise Pascal, Institut Pascal, 63000 Clermont-Ferrand, France CNRS, SIGMA Institut Pascal, F-63171 AUBIERE, France.

, IRT, BP 14070, Libreville, Gabon

N. Manfoumbi

Université des Sciences et Techniques de Masuku, BP 901 Franceville, Gabon

ABSTRACT: This paper focuses on the mechanical behavior of Ozigo wood beams subjected to long-term creep in three environments (air-conditioned inside a building, outside unsheltered and outside sheltered). The purpose is to develop a database that will be useful to evaluate the influence of spatial variability of mechanical parameters/properties on the reliability of beams with or without cracks. To this aim, three points bending tests were performed on 81 specimens at laboratory scale. The results obtained show a significant spatial variability for specimens belonging to the same beam. It was also found that the mean modulus of elasticity (MOE) and the failure stress (FS) of the air-conditioned beam are greater than the same parameters measured at unsheltered and sheltered environments.

Keywords: Spatial variability; Timber; Ozigo, Modulus of Elasticity; Failure Stress; Dacryodes buettner

\section{INTRODUCTION}

Since 1950, almost all Gabonese forest production is exported. Before 2010 , the law required that $75 \%$ of the logs were treated locally but the analyzes show that only $25 \%$ to $35 \%$ were treated before this date. It is why the Gabonese government, in the perspective of an emerging Gabon, decided to ban log exports since January 2010, paving the way for local processing and extension of tropical species in local and sub-regional buildings. However, the mechanical behavior of tropical woods in their environment is a real challenge for the prediction of the behavior of tropical timber structures subject to thermo-hygro mechanical loads (Pambou Nziengui et al. 2017).

Several studies found that the consideration of the spatial variability is crucial to improve the reliability.

\section{MATERIAL AND METHODS}

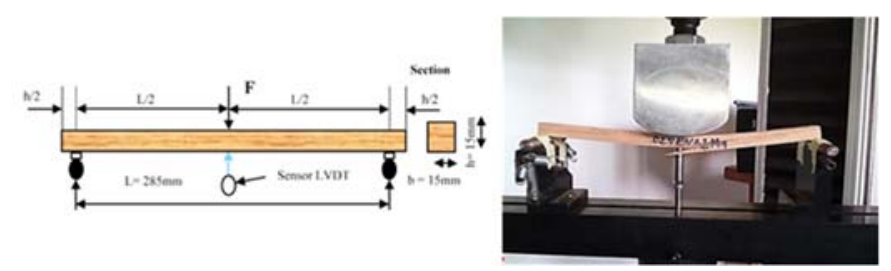

Figure 1. Experimental device for three-point bending tests

\subsection{Materials and environment of the study}

The specimens were extracted from three wooden beams Dacryodes buettneri $(89 \mathrm{~mm} \times 176 \mathrm{~mm} \times 3090$ $\mathrm{mm})$ previously subjected to a creep test in tropical atmospheres and three previously mentioned environments during 9 years (Figures $2 \mathrm{a}$ to $2 \mathrm{c}$ ). These beams were sawn into nine sections $340 \mathrm{~mm}$ long. These sections are subdivided into three portions in height referred here as upper, middle and lower, (Figures $2 \mathrm{~d}$ and 2e). Among these specimens, only three (right side) were tested by section ( 81 test pieces of section $15 \mathrm{~mm} \times 15 \mathrm{~mm}$ and $300 \mathrm{~mm}$ long).

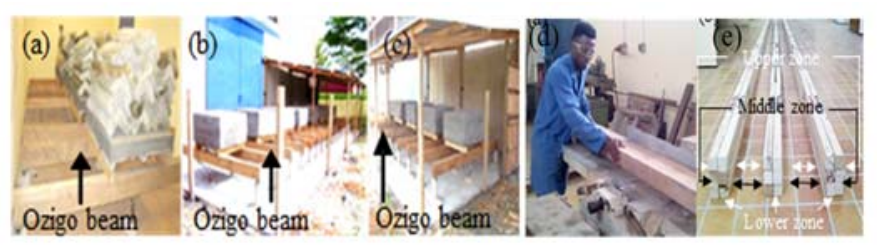

Figure 2. a) Air-conditioned environment. b) Unsheltered outdoor environment. c) Sheltered outdoor environment d) Alignment of the beam. (e) Test specimens for the characterization of spatial variability. 


\section{RESULTS AND DISCUSSION}

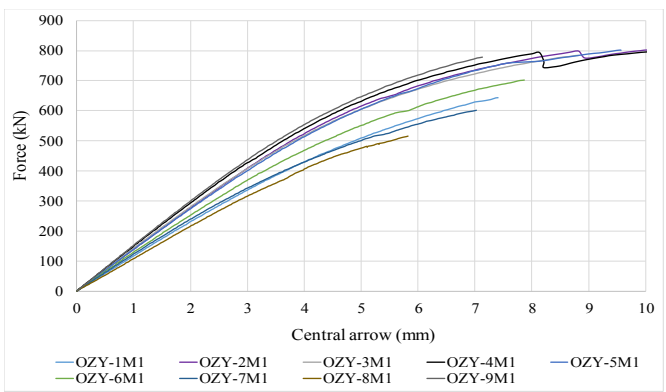

Figure 3. Force vs central arrow results for specimens at upper part in air-conditioned environment.

Figure 3 presents the spatial distribution of the values of MOE obtained from results such as given in Figure 4. We note that the average MOE (for all the specimens) is $11697.05 \mathrm{MPa}$; this result is slightly higher $(15 \%)$ than the MOE reported in Manfoumbi (2012) $10700 \pm 1550 \mathrm{MPa}$ but it is lower $(9 \%)$ than the value given in CIRAD (2011) which is $13820 \pm$ $2273 \mathrm{MPa}$.

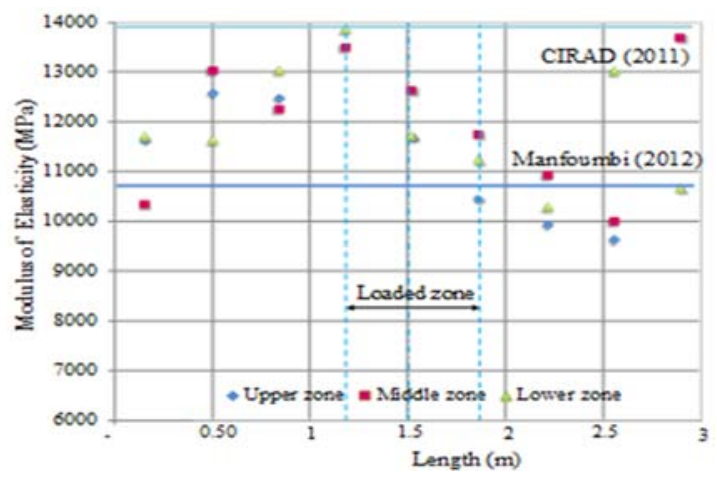

Figure 4. Spatial distribution of MOE for the air-conditioned environment

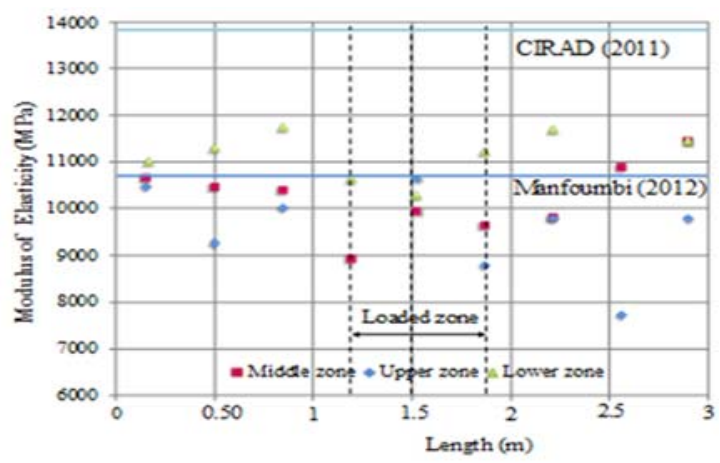

Figure 5. Spatial distribution of MOE for the unsheltered outdoor environment

Figure 5. We observe that the calculated average MOE is $10318.65 \mathrm{MPa}$ of the beam is $4 \%$ lower than the results obtained by Manfoumbi (2012) and 25\% smaller than the reported by the CIRAD (2011).

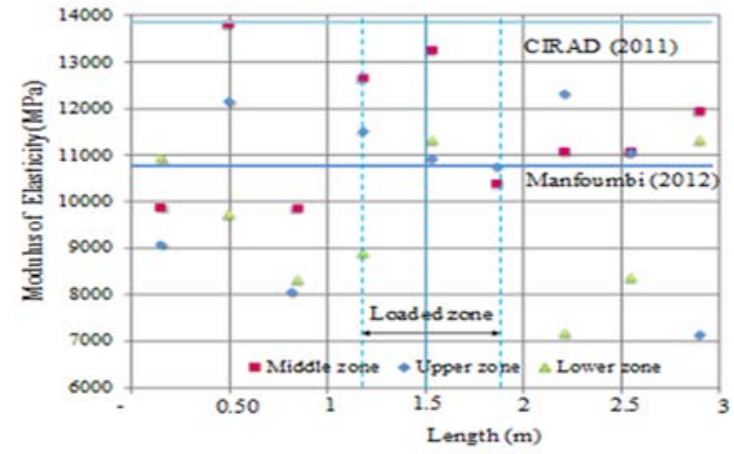

Figure 6. Spatial distribution of MOE for the sheltered outdoor environment

The MOE (10460.48 MPa) of the sheltered outdoor environment is respectively $2 \%$ and $24 \%$ lower than those reported by Manfoumbi (2012) and CIRAD (2011).

\section{CONCLUSIONS AND OUTLOOK}

The spatial variability of MOE and the FS after threebending test of specimens submitted to long-term loading in specific environment have been presented. The results show that the MOE of the beam in airconditioned medium is greater to the MOE of the beam in unsheltered and sheltered outdoor environments. This drop-in rigidity is due to the aging of the material, the duration of loading, climatic effects and exposures of beams to environments exteriors.

The overall results indicate that there is a real spatial variability of the studied parameters. The results obtained in this phase will be completed with more 3-points binding tests as well as compression and traction test to complete the database. This database will be useful for characterizing and then generating "random fields" taking into account the uncertainties and spatial variability of these parameters.

\section{REFERENCES}

CIRAD, (2011). Département Forêts, « TROPIX 5.0: Caractéristiques technologiques de 215 essences tropicales ", Edition CIRAD.

Manfoumbi N (2012). Contribution à l'adaptation de l'Eurocode 5 aux essences tropicales dans leur environnement. Thèse de doctorat: genie civil. Limoges: Université de Limoges, 2012.http://epublications.unilim.fr/theses/2012/manfoumbiboussougounicaise/manfoumbiboussougou-nicaise.pdf.

Pambou Nziengui C.F., Ikogou S., Moutou Pitti R. (2017). Impact of cyclic compressive loading and moisture content on the mechanical behavior Aucoumea Klaineana Pierre. Wood Material Science and Engineering, 13, 190-196.

\section{ACKNOWLEDGEMENTS}

The authors thank the direction of the National School of Water and Forests (ENEF) of Gabon for the mechanics Laboratory and housing put at their disposal. 